\title{
Evidence for cell apoptosis suppressing white spot syndrome virus replication in Procambarus clarkii at high temperature
}

\author{
Xiao-Guo Wu, Hai-Tao Xiong, Yi-Zhen Wang, Hua-Hua Du* \\ Key Laboratory of Molecular Animal Nutrition, Ministry of Education, Feed Science Institute, Zhejiang University, \\ Hangzhou 310029, PR China
}

\begin{abstract}
In shrimp, higher water temperatures $\left(\sim 32^{\circ} \mathrm{C}\right)$ can suppress the ability of white spot syndrome virus (WSSV) to replicate and cause mortality, but the mechanisms remain unclear. To investigate whether cell apoptosis might be involved, a Tdt-mediated dUTP nick-end label (TUNEL) method was used to assess levels of chromosomal DNA fragmentation in hepatopancreas and gill cells of Procambarus clarkii crayfish infected with WSSV and maintained at either $32 \pm 1^{\circ} \mathrm{C}$ or $24 \pm 1^{\circ} \mathrm{C}$. Based on relative cell numbers with yellow-green colored TUNEL-positive nuclei, the apoptotic index was elevated in WSSV-infected crayfish maintained at $32^{\circ} \mathrm{C}$. In gill tissue sections examined by transmission electron microscope, cells with nuclei displaying apoptotic bodies or marginated, condensed and fragmented chromatin without concurrent cell cytoplasm damage were also more prevalent. Flow cytometry sorting of annexin-stained cells showed apoptosis to be most prevalent in granular haemocytes, and assays for caspase-3 activity showed it to be most elevated in hepatopancreas tissue. Despite these indicators of cell apoptosis but consistent with WSSV replication being restricted at elevated temperatures, no increases in transcription of the viral anti-apoptosis genes ORF390 and ORF222 were detected by RT-PCR in shrimp maintained at $32^{\circ} \mathrm{C}$, possibly due to the elevated levels of cellular apoptosis.
\end{abstract}

KEY WORDS: WSSV $\cdot$ Crayfish $\cdot$ TUNEL

Resale or republication not permitted without written consent of the publishe

\section{INTRODUCTION}

Since it first emerged in the early 1990s, white spot disease (WSD) has spread to severely impact aquaculture of penaeid shrimp and other crustaceans in most regions of the world (Lightner 1996). WSD is caused by white spot syndrome virus (WSSV), an enveloped rod-shaped virus containing a large ( 300 kb) double-stranded DNA (dsDNA) genome classified in the genus Whispovirus of the family Nimaviridae (Vlak 2004), and can result in complete losses of shrimp in farm ponds within 3 to $10 \mathrm{~d}$ of gross signs becoming evident (Wang et al. 1998). However, WSD outbreaks tend to occur less frequently during warm seasons (Withyachumnarn- kul et al. 2003). Bioassays at various water temperatures have indicated that while 24 to $28^{\circ} \mathrm{C}$ is ideal for WSSV to replicate and induce mortality (Vidal et al. 2001, Du et al. 2006, You et al. 2010), its replication and thus ability to cause mortality in either shrimp (Vidal et al. 2001) or crayfish (Du et al. 2006, Gao et al. 2011) is suppressed at temperatures above $\sim 32^{\circ} \mathrm{C}$. Shrimp cultivation during summer months is now accepted widely as a practical means of reducing WSD impact. It has been suggested that this protective effect is not due exclusively to temperature-mediated inhibition of viral replication (Vidal et al. 2001, Jiravanichpaisal et al. 2004); however, the mechanisms involved have yet to be elucidated. 
Apoptosis is a distinctive mechanism of programmed cell death that can be triggered in response to cell invasion by viruses (O'Brien 1998), thus limiting virus shedding and spread (Barber 2001), and is the main adaptive anti-viral response mounted by terrestrial invertebrates (Koyama et al. 2000). Cell apoptosis has been suggested as a possible mechanism by which Litopenaeus vannamei shrimp survive WSSV infection when maintained at $32^{\circ} \mathrm{C}$ (Granja et al. 2003). Thus, to investigate this possibility further, approaches to detecting and quantifying cell apoptosis levels including the Tdt-mediated dUTP nick-end label (TUNEL) assay, a caspase-3 activity assay, flow cytometry of annexin-stained haemocytes as well as transmission electron microscopy (TEM) were undertaken on crayfish Procambarus clarkii acclimated to moderate $\left(24^{\circ} \mathrm{C}\right)$ or high $\left(32^{\circ} \mathrm{C}\right)$ water temperatures before challenge with WSSV.

\section{MATERIALS AND METHODS}

\section{Virus}

The WSSV stain used originated from wild Penaeus chinensis collected from the East China Sea in 2001. Using a homogenate of gill tissue from experimentally infected Procambarus clarkii, a semi-purified virus inoculum was prepared using the differential centrifugation method described previously (Du et al. 2007) and stored at $-80^{\circ} \mathrm{C}$.

\section{Crayfish}

Adult Procambarus clarkii (15-20 g, 8-10 cm long) were purchased from Hangzhou, China, and maintained in $40 \mathrm{l}$ tanks $(100 \times 50 \times 55 \mathrm{~cm})$ containing sand-filtered, ozone-treated, flow-through freshwater. Crayfish were fed with commercial feed pellets at $5 \%$ of body weight per day. When being acclimated at 24 $\pm 1^{\circ} \mathrm{C}$ for a week, a small pleopod piece was excised from each crayfish to confirm absence of WSSV by PCR as described previously (Du et al. 2006).

\section{Experimental design}

Crayfish were acclimated for $3 \mathrm{~d}$ at either $24 \pm 1^{\circ} \mathrm{C}$ or $32 \pm 1^{\circ} \mathrm{C}$. At each temperature, 2 groups of 30 Procambarus clarkii were infjected intra-muscularly with $0.1 \mathrm{ml}$ WSSV inoculum per crayfish. A control group of crayfish injected with $0.1 \mathrm{ml} 330 \mathrm{mM} \mathrm{NaCl}$ was also maintained at $32 \pm 1^{\circ} \mathrm{C}$. At various times $(0,24,48,60$, 72, and $96 \mathrm{~h}$ ) post-infection (hpi), 5 crayfish were sacrificed at random from each group for analysis.

PCR and real-time quantitative PCR

DNA was extracted from gill tissue using the Viral DNA Extracted Kit (Sangon) according to the manufacturer's instructions. DNA pooled from 3 crayfish at each time point was amplified by PCR using the WSSV 334F/R primers as described previously (Du et al. 2006) and PCR products were analyzed in $2 \%$ agarose gels.

Real-time quantitative PCR (qPCR) based on the 69F/R primers described previously (Durand \& Lightner 2002) was used to amplify and quantify WSSV DNA relative to a 69 bp plasmid DNA internal standard. Plasmid DNA was purified and quantified to calculate DNA copy number. Standard curves were constructed from qPCR data on 10-fold serial dilutions containing $10^{8}$ to 10 plasmid DNA copies. The qPCR used the Step One plus Real-time PCR System (ABI Applied Biosystems) and Bio-Easy SYBR Green Kits (Bioer). WSSV DNA copies in any sample were determined from the standard curve.

\section{TUNEL assay}

Gill and hepatopancreas tissues preserved in Davidson's fixative were prepared into paraffin wax and sectioned using standard methods (Lightner 1996). Apoptotic cells were detected using an In Situ Cell Death Detection TUNEL Assay Kit (Roche) as described in the manufacturer's protocol. Tissue sections were counterstained using a Cell Apoptosis Propidium Iodide (PI) Detection Kit (Keygen) and observed immediately by fluorescence microscopy using a green filter to detect DNA fragmentation (TUNEL-positive cells) and a red filter to highlight the cell nucleus. An apoptotic index (AI) was calculated as the percentage of TUNEL-positive nuclei per 500 cells across an ocular grid at 400× magnification. Positive controls comprised tissues from uninfected crayfish digested with DNase I to fragment nuclear DNA before processing. Negative controls comprised normal tissues treated identically but without addition of TdT enzyme.

\section{Transmission electron microscopy}

Gill tissues of WSSV-infected crayfish were fixed in $2.5 \%$ glutaraldehyde at $4^{\circ} \mathrm{C}$ for $24 \mathrm{~h}$, post-fixed 
in $1 \%$ osmium tetroxide, dehydrated through graded ethanol concentrations and embedded in Aradite-502 resin. Ultrathin sections (60 to $90 \mathrm{~nm}$ ) of silver-gray interference were collected on copper grids, stained with uranyl acetate/lead citrate and viewed using a Hitachi H-300 electron microscope.

Flow cytometry

Apoptotic cells in haemolymph were labeled using the fluorescein EGFP-Annexin V Apoptosis Detection Kit (Keygen) following the manufacture's protocol and quantified using a standard fluorescence-activated cell analyzer (FACScalibur, Becton Dickinson). EGFP-Annexin V labels phosphatidylserine relocated from inner to outer cell membranes at the early apoptotic stage, and PI was used to stain cellular DNA. Data were expressed as 2-dimensional dot plots and contour plots. For each haemolymph sample, 5000 haemocytes were acquired for analysis and data presented as a cell cytogram of low-angle forward-scattered (FSC) and right-angle side-scattered (SSC) laser light in linear mode (Cellquest Software). The granular cells indicative of WSSV infection stained with both EGFP-Annexin V and PI, and were analyzed as histograms at green fluorescence (FL1) and red fluorescence (FL2) heights in linear mode (Cellquest Software).

\section{Caspase-3 activity assay}

Caspase-3 activities in crayfish hepatopancreas tissues were measured using a colorimetric Caspase-3 Assay Kit (Keygen) as described in the manufacturer's protocols. Briefly, tissues were disrupted in Lysis buffer, the protein concentration adjusted to $2 \mu \mathrm{g} \mu \mathrm{l}^{-1}$ and 3 replicate $50 \mu \mathrm{l}$ amounts were added to a equal volume of reaction buffer before determining optical density (OD) as absorbance with a wavelength of $405 \mathrm{~nm}\left(\mathrm{~A}_{405 \mathrm{~nm}}\right)$ using a Multiskan Spectrum spectrophotometer (Molecular Devices). Caspase-3 activity was expressed as $\left(\mathrm{OD}_{\text {infected }}-\right.$ $\left(\mathrm{OD}_{\text {blank }}\right) /\left(\mathrm{OD}_{\text {control }}-\mathrm{OD}_{\text {blank }}\right)$.

\section{Semi-quantitative RT-PCR}

Total RNA was extracted from gills using TRIzol reagent (Invitrogen), purified by RNAclean RNA Kit (Aidlab) and reverse transcribed using the First-
Strand cDNA Synthesis kit (Fermentas). cDNA pooled from 3 crayfish at each time point $(0,24,48,72$ and 96 hpi) was amplified by PCR using primers targeted to 2 anti-apoptosis genes: the ORF390 gene (F, 5'TAA GCG GGA AAG AGT AAA-3'; R, 5'-TAG GGT GAT GAG GGT C-3') and ORF222 gene (F, 5'-CTA GCC AAC ACC TAT CCG-3'; R, 5'-TGA GTT CAA GGG CAG ATT-3') (Wang et al. 2004, Fang et al. 2006). As a control for qualification, host $18 \mathrm{~S}$ ribosomal RNA was also amplified using PCR primers ( $F$, 5'-GAC CAG AGC GAA AGC ATT-3'; R, 5'-TCC ACC AAC TAA GAA CGG-3').

\section{Statistical analysis}

All measurements were made in duplicate. The data were analyzed using 1-way ANOVA in SPSS 16.0. Differences were considered as significant at $\mathrm{p} \leq 0.05$.

\section{RESULTS AND DISCUSSION}

Prior to injecting Procambarus clarkii crayfish with WSSV, the absence of pre-existing infection was confirmed by PCR analysis. At the first sampling point after challenge (24 hpi), WSSV was detected by both PCR and qPCR using DNA isolated from gill tissues of crayfish held in both $24^{\circ} \mathrm{C}$ (ambient) and $32^{\circ} \mathrm{C}$ (high) temperature water (Fig. 1A). In crayfish maintained at $24^{\circ} \mathrm{C}$, WSSV DNA copy numbers quantified by qPCR increased $~ 1000$-fold $\left(2.3 \times 10^{4}\right.$ to $\left.2.2 \times 10^{7}\right)$ between 24 and 96 hpi (Fig. 1B). In crayfish maintained at $32^{\circ} \mathrm{C}$, however, WSSV DNA copy numbers reduced from $1.0 \times 10^{4}$ to $1.4 \times 10^{3}$ between 24 and $60 \mathrm{hpi}$, after which they remained stable (Fig. 1B). Non-progression of WSSV infection in crayfish maintained at $32^{\circ} \mathrm{C}$ is consistent with previous reports of elevated temperatures hindering replication (Du et al. 2006, Granja et al. 2006, Rahman et al. 2006, Gao et al. 2011).

To examine for DNA fragmentation and morphological changes indicative of cell apoptosis, crayfish tissues were examined using a TUNEL assay and TEM, respectively. In gill and hepatopancreas tissues, no TUNEL-positive cells were detected in uninfected Procambarus clarkii except when tissue was digested with DNase I to purposely fragment DNA as a control (Fig. 2A). In tissues of WSSV-infected crayfish sampled at 48 and maintained at $24^{\circ} \mathrm{C}$, there were scattered apoptotic cells, but among those maintained at $32^{\circ} \mathrm{C}$, yellow-green colored TUNEL- 

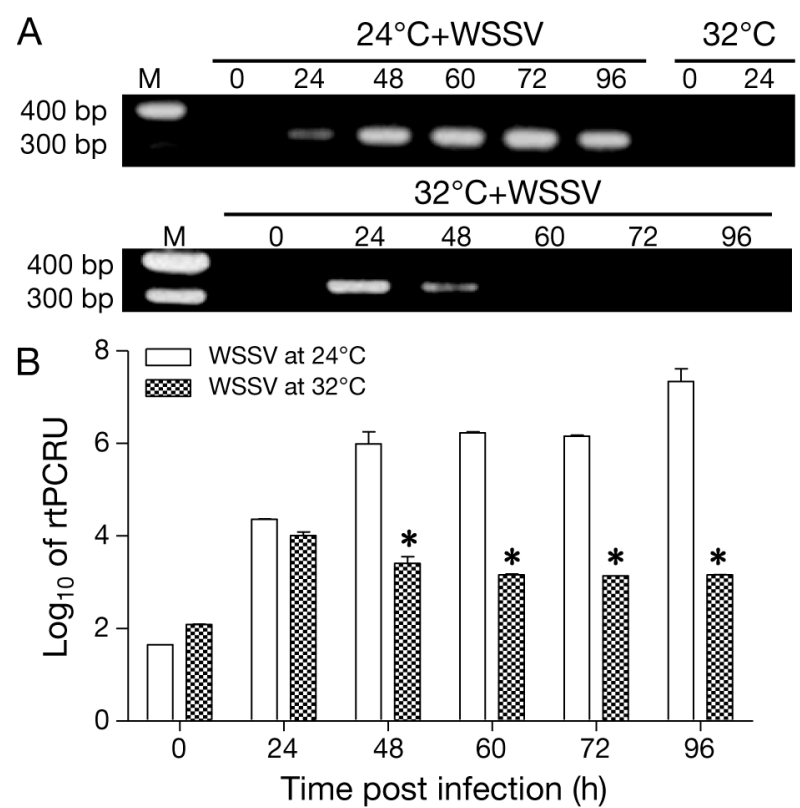

Fig. 1. White spot syndrome vorus (WSSV) detection in Procambarus clarkii at $24^{\circ} \mathrm{C}$ and $32^{\circ} \mathrm{C}$. (A) One-step PCR amplification of WSSV DNA from gills of crayfish maintained at either $24^{\circ} \mathrm{C}$ or $32^{\circ} \mathrm{C}$ and sampled before and after $24 \mathrm{~h}$ acclimation at $32^{\circ} \mathrm{C}$ or sampled immediately before WSSV infection or between 24 and $96 \mathrm{~h}$ post-infection (hpi) with WSSV. $\mathrm{M}=$ DNA marker. (B) WSSV DNA quantification by real-time quantitative PCR. Data are mean $+\mathrm{SD}$ of $\log _{10}$ real-time PCR units (rtPCRU) from 2 replicate tests of DNA pooled from 3 crayfish. *Statistically significant differences $(p<0.05)$ between WSSV replication rates at the 2 incubation temperatures

positive nuclei were ubiquitous (Fig. 2A), consistent with increased rates of apoptosis. From 48 to $96 \mathrm{hpi}$, AI values (\% TUNEL-positive nuclei per 500 cells) were elevated significantly ( $<0.05$ ) across both gill and hepatopancreas tissues of WSSV-infected crayfish maintained at $32^{\circ} \mathrm{C}$ compared to $24^{\circ} \mathrm{C}$ (Fig. 2B). In addition, at both $32^{\circ} \mathrm{C}$ and $24^{\circ} \mathrm{C}$, the AI peaked earlier and at higher levels in gills at $48 \mathrm{hpi}(27.7 \%$ and $19.2 \%)$ than in hepatopancreas at $60 \mathrm{hpi}(15.2 \%$ and $10.4 \%$ ) before declining to similar levels at 72 hpi at both temperatures (Fig. 2B). This more pronounced increase and then degradation of apoptotic cells in P. clarkii maintained at $32^{\circ} \mathrm{C}$ provides clues as to how WSSV replication and cell-cell spread is precluded at elevated temperatures.

In Procambarus clarkii maintained at $24^{\circ} \mathrm{C}$ and sampled prior to WSSV infection, TEM showed gill cells to contain normal nuclei with heterochromatin in peripheral patches and as a central mass (Fig. 3A). At 72 hpi with WSSV, however, gill cell nuclei displayed dense ring-like zones containing marginated chromatin (Fig. 3B,C,D). Enveloped WSSV particles were first observed at $48 \mathrm{hpi}$ (Fig. 3C), and at $96 \mathrm{hpi}$, some enlarged nuclei displayed dense marginated chromatin around a central zone containing rod-like viral particles as well as ruptured nuclear membranes (Fig. 3E). In contrast to the crayfish maintained at $24^{\circ} \mathrm{C}$, the nuclei of gill cells of those acclimated at $32^{\circ} \mathrm{C}$ for $3 \mathrm{~d}$ prior to WSSV challenge showed a broad zone of dense and marginated chromatin (Fig. 4A), suggesting that exposure to this temperature alone promoted apoptosis. In crayfish sampled over time following WSSV challenge, nuclear chromatin was observed to condense and fragment, with disruption of presumed nucleolar structures (Fig. 4B,C,D). Apoptotic bodies containing nuclear material were also frequently observed in intercellular spaces (Fig. 4E). In addition, no WSSV particles were ever observed in cells undergoing apoptotic changes (Fig. 4), confirming the inability of WSSV to replicate in such cells.

While the TUNEL assay and TEM reliably identify individual apoptotic cells, they provide only qualitative data on cell apoptosis levels. A flow cytometry (FCM) method based on reduced DNA staining by PI and cell shrinkage was thus used to quantify cells undergoing apoptosis (Sahul Hameed et al. 2006). Of the 3 haemocyte types in crayfish, only semi-granular and granular cells can be infected by WSSV (Wang et al. 2002), and granular cells play an important role in the innate immune system of shrimp (Söderhäll \& Cerenius 1998). FCM analysis of cell morphology and cell granularity using FSC and SSC light scattering, respectively, was used to distinguish viable cells not binding to either PI or EGFP-Annexin- $V$, necrotic cells binding both EGFP-Annexin-V and PI, apoptotic cells not binding EGFP-Annexin-V but binding PI, as well as naked nuclei to estimate apoptosis levels in granular cells (Fig. 5Ai). Using these methods, apoptotic cells could be separated and quantified in linear histograms comparing green fluorescence (FL1) and red fluorescence (FL2) heights (Fig. 5Aii). In WSSV-infected crayfish, the FCM data confirmed TUNEL and TEM data, indicating that apoptosis of granular haemocytes was more prevalent in crayfish maintained at $32^{\circ} \mathrm{C}$ than at $24^{\circ} \mathrm{C}$ (Fig. 5B) and increased with time post-challenge (Fig. 5B), which supports evidence on WSSV infection triggering cell apoptosis in penaeid shrimp (Sahul Hameed et al. 2006).

As cleavage of many key proteins by caspase- 3 is critical for cell apoptosis (Gerald 1997), caspase-3 activity was also investigated in hepatopancreas cells. In Procambarus clarkii acclimated at $32^{\circ} \mathrm{C}$ compared to $24^{\circ} \mathrm{C}$, activity was significantly higher ( $\mathrm{p} \leq$ 

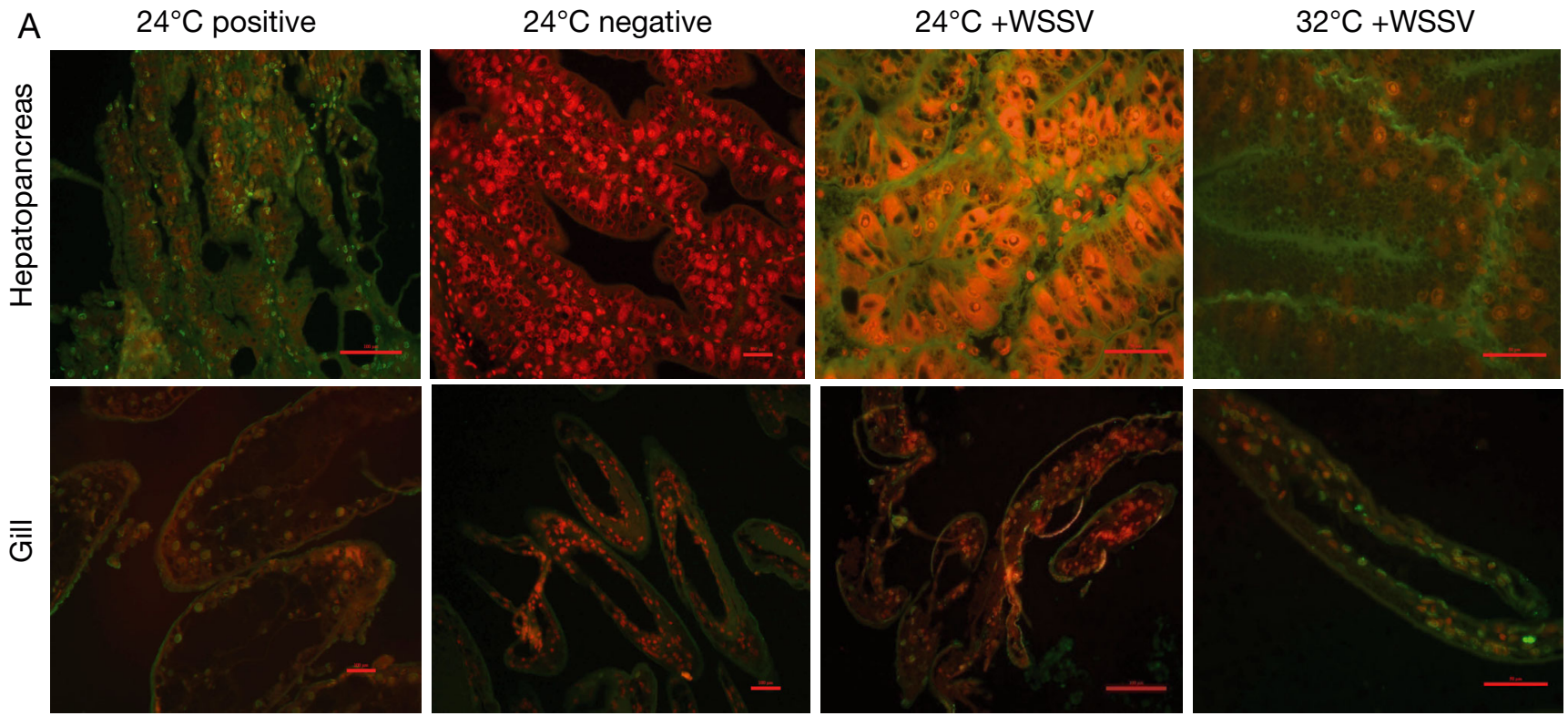

B
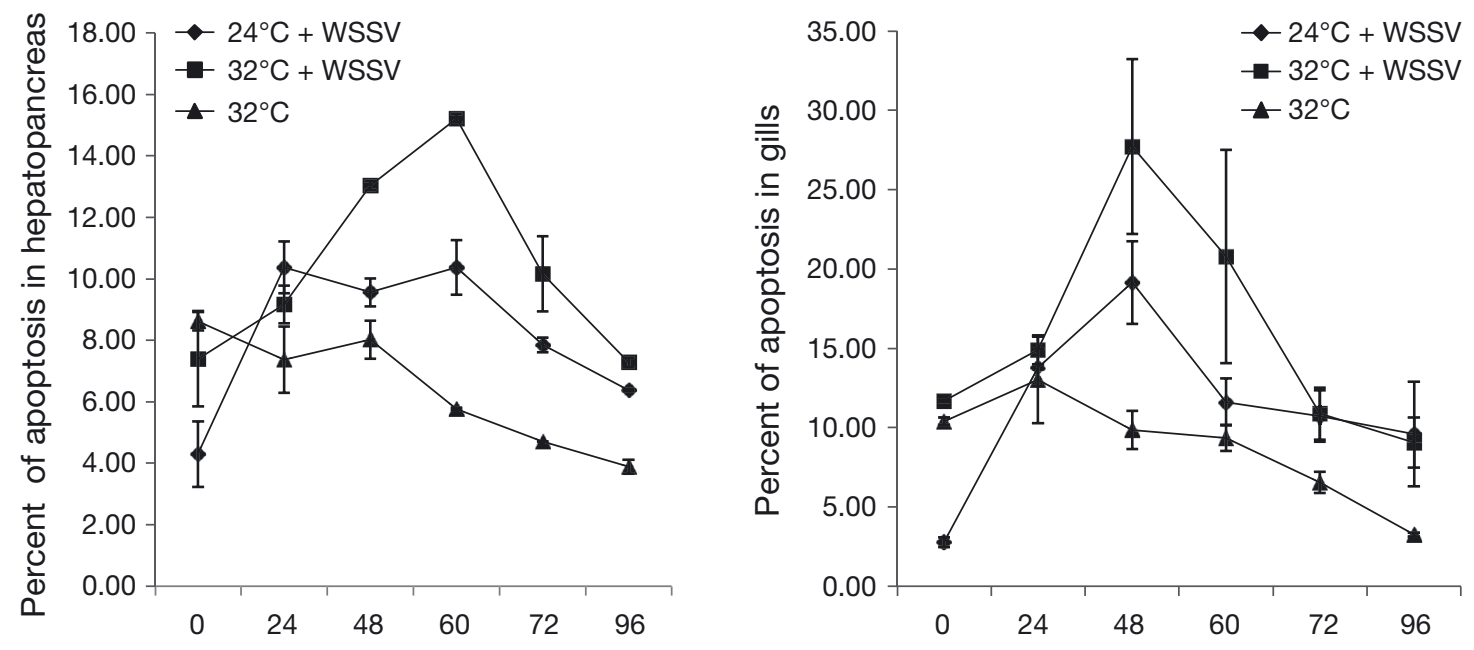

Hours post WSSV infection

Fig. 2. (A) Fluorescence microscopy of contiguous sections of Tdt-mediated dUTP nick-end label (TUNEL)-stained hepatopancreas and gill tissue of WSSV-infected Procambarus clarkii maintained at either $24^{\circ} \mathrm{C}$ or $32^{\circ} \mathrm{C}$. Positive (control): DNase Itreated tissues showing nuclei displaying yellow-green fluorescence typical of TUNEL staining (scale bars $=100 \mu \mathrm{m}) ;$ negative (control): untreated tissues showing only the red fluorescent counterstain (scale bars $=100 \mu \mathrm{m}$ ) $;+$ WSSV: WSSV-infected crayfish, sampled at $48 \mathrm{~h}$ post-infection (hpi) (scale bars $=50 \mu \mathrm{m})$. (B) Apoptosis index ( $\%$ apoptotic cells, mean \pm SEM), calculated from numbers of TUNEL-positive cells detected in hepatopancreas and gill tissue from WSSV-infected crayfish maintained at either $24^{\circ} \mathrm{C}$ or $32^{\circ} \mathrm{C}$

0.01 ) both pre-challenge and at all times post-infection with WSSV. Activity levels at both temperatures peaked between 60 and $72 \mathrm{hpi}$ before returning to more normal levels at 96 hpi (Fig. 6).

RT-PCR tracking of mRNA expression levels of the anti-apoptosis genes ORF390 and ORF222 showed both to increase, although more so in crayfish maintained at $24^{\circ} \mathrm{C}$ than at $32^{\circ} \mathrm{C}$ (Fig. 7). In addition, while expression levels continued to increase (ORF390) or to stabilize (ORF222) from 48 hpi onwards in crayfish maintained at $24^{\circ} \mathrm{C}$, decreases in both were evident at $96 \mathrm{hpi}$ in crayfish maintained at $32^{\circ} \mathrm{C}$. These data provided no new information on whether elevated temperature itself and/or elevated cell apoptosis as a result of crayfish being maintained at $32^{\circ} \mathrm{C}$ restricted WSSV replication. 

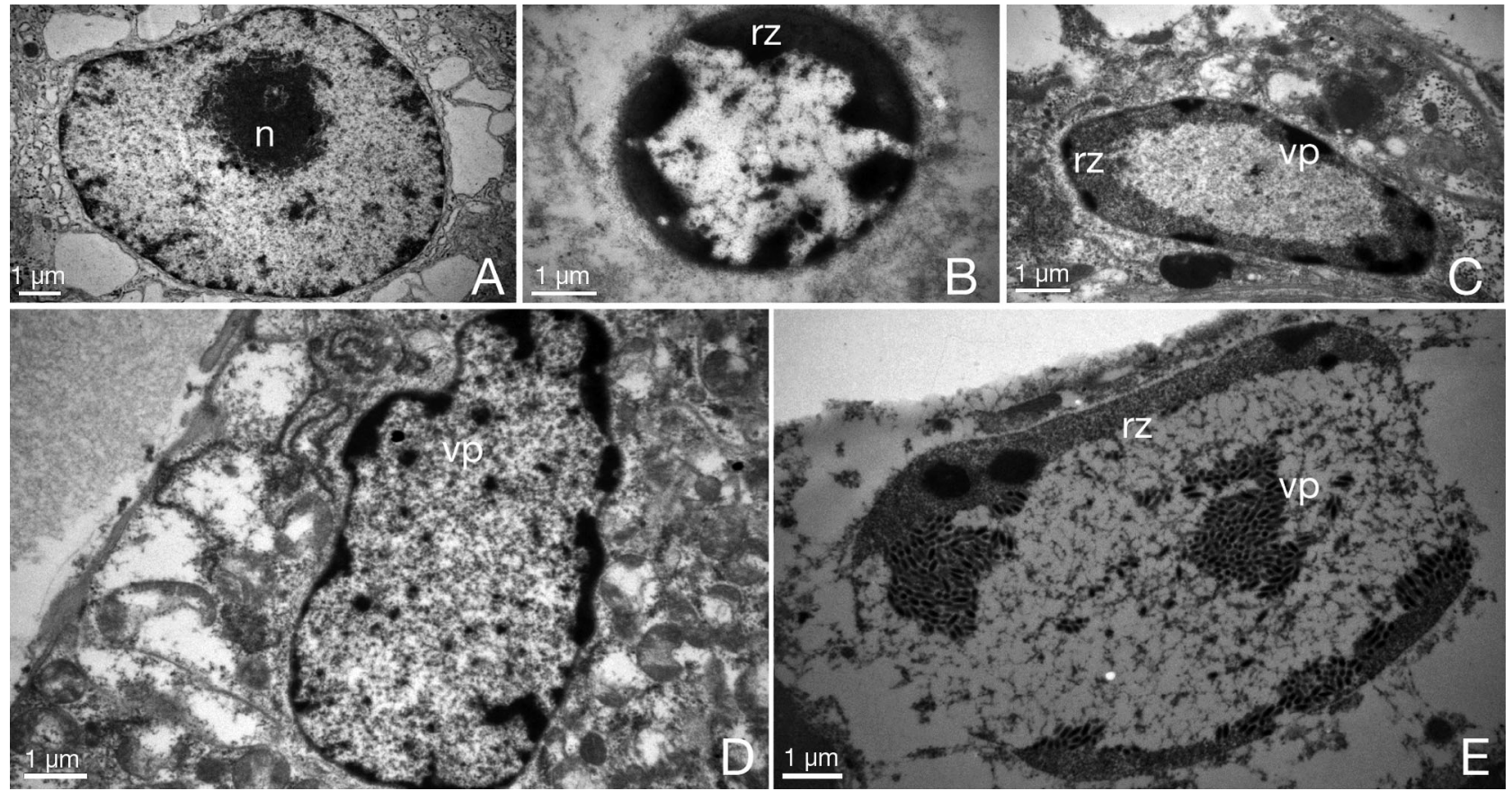

Fig. 3. Transmission electron micrographs of gills of WSSV-infected Procambarus clarkii maintained at $24^{\circ} \mathrm{C}$. (A) 0 h postinfection (hpi): normal nuclei (n); (B) 24 hpi: nucleus showing dense ring-like zone (rz) containing marginated chromatin; (C) 48 hpi: enlarged nucleus showing a dense rz and a small number of viral envelopes and particles (vp); (D) 72 hpi: enlarged nucleus with thin rz and many vp; (E) 96 hpi: damaged nucleus containing high density of vp; thin rz containing little marginated chromatin with vp appearing to be released from the nucleus. Scale bars $=1 \mu \mathrm{m}$
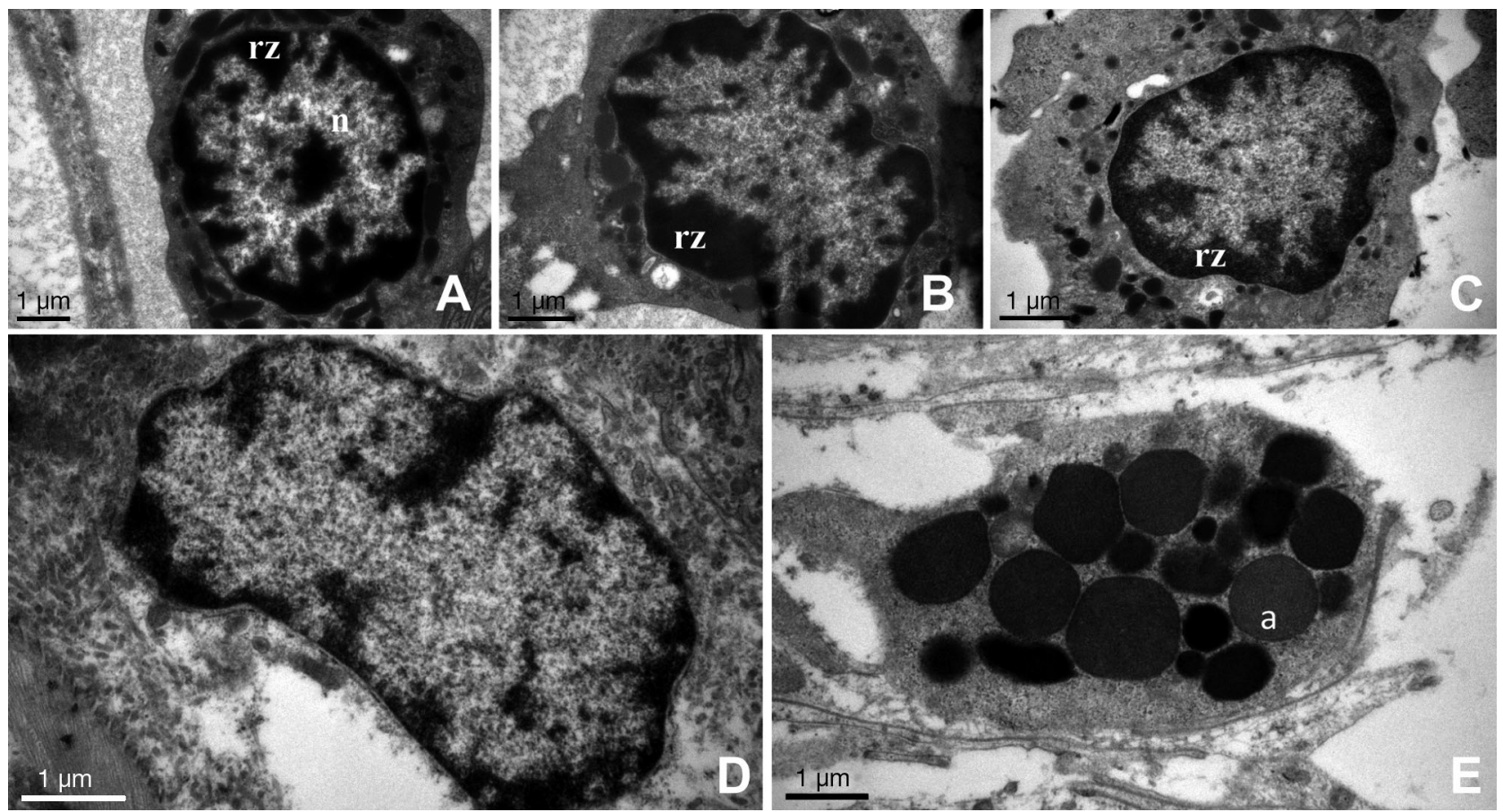

Fig. 4. Transmission electron micrographs of gills of WSSV-infected Procambarus clarkii maintained at $32^{\circ} \mathrm{C}$. (A) 0 h postinfection (hpi): slightly enlarged nucleus with chromatin margination; (B) 24 hpi: enlarged nucleus showing a dense ring-like zone (rz) or marginated chromatin; (C) 48 hpi: enlarged nucleus showing a dense rz or marginated chromatin without viral particles (vp) in the central region; (D) $72 \mathrm{hpi}$ : thin rz containing little marginated chromatin but no vp observed in the nucleus; (E) 96 hpi: apoptotic bodies (a) containing nuclear fragments in intercellular spaces in gill cells and increased cytoplasmic vacuolization around nucleus. Scale bars $=1 \mu \mathrm{m}$ 

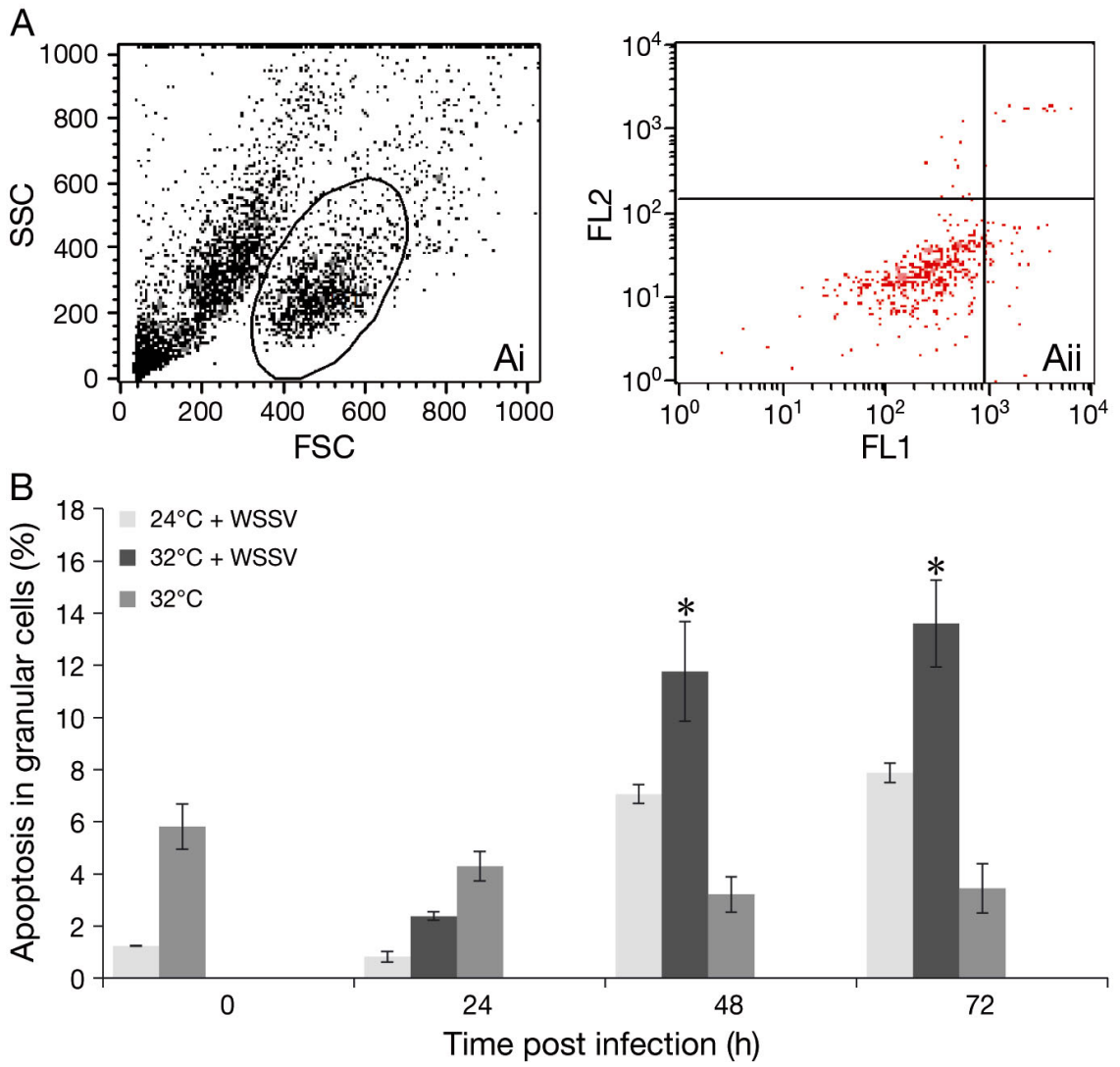

Fig. 5. Flow cytometry analysis of apoptotic granular haemocytes in WSSV-infected Procambarus clarkii at $24^{\circ} \mathrm{C}$ and $32^{\circ} \mathrm{C}$. (Ai) Dot plot analysis of haemocytes at $32^{\circ} \mathrm{C}$ stained with EGFP-Annexin- $\mathrm{V}$ and propidium iodide (PI) comparing forward scatter (FSC), which measures relative cell size, with side scatter (SSC), which measures cell granularity. For apoptosis analysis, granular cells were gated. (Aii) Dot plot analysis at $32^{\circ} \mathrm{C}$ showing viable cells not binding to either PI or EGFP-Annexin-V (lower left quadrant), necrotic cells binding both EGFP-Annexin-V and PI (upper right quadrant) and apoptotic cells not binding EGFP-Annexin-V but binding PI (lower right quadrant) with green fluorescence (FL1) or red fluorescence (FL2). (B) Percentage apoptotic granular cells (mean \pm SEM) determined by flow cytometry analysis of haemocytes collected from Procambarus clarkii following WSSV infection (+WSSV). *Statistically significant differences $(p<0.05)$ among results from control (uninfected) and the 2 incubation temperatures

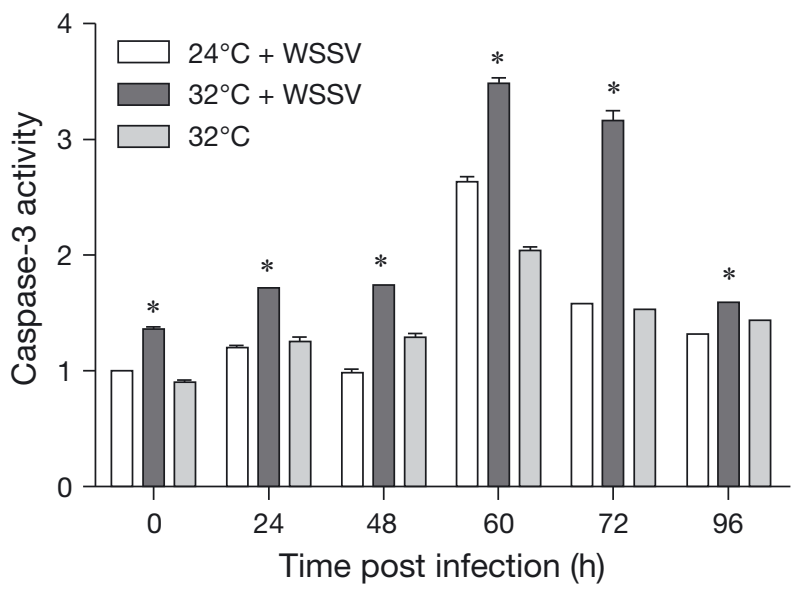

Fig. 6. Caspase- 3 activity (mean \pm SEM) in hepatopancreas tissue of Procambarus clarkii maintained at $24^{\circ} \mathrm{C}$ or $32^{\circ} \mathrm{C}$ sampled following WSSV infection, expressed as a measure of optical density (OD) at $440 \mathrm{~nm}$, and calculated as $\left(\mathrm{OD}_{\text {experiment }}-\mathrm{OD}_{\text {blank }}\right) /\left(\mathrm{OD}_{\text {control }}-\mathrm{OD}_{\text {blank }}\right){ }^{*}$ Statistically significant differences $(p<0.01)$ among results from control (uninfected) and the 2 incubation temperatures

In WSSV-infected penaeid shrimp, progressive increases in apoptotic cells associated with disease severity has been implicated as a factor contributing to organ failure, morbidity and ultimately to death (Sahtout et al. 2001, Khanobdee et al. 2002). In the

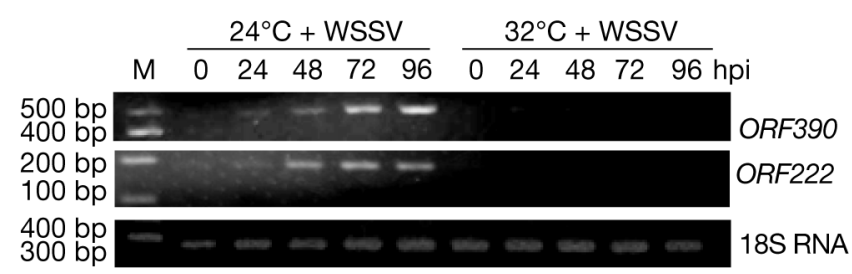

Fig. 7. RT-PCR amplification of ORF390 and ORF222 mRNA in gills of Procambarus clarkii maintained at $24^{\circ} \mathrm{C}$ and $32^{\circ} \mathrm{C}$ and sampled following WSSV infection. As a control, 18S rRNA was amplified by RT-PCR from the same RNA samples

Procambarus clarkii examined here, acclimation to $32^{\circ} \mathrm{C}$ water for $3 \mathrm{~d}$ resulted in increased levels of cellular apoptosis compared to crayfish left in ambient temperature $\left(24^{\circ} \mathrm{C}\right)$ water, and WSSV challenge increased apoptosis rates more in the crayfish maintained at $32^{\circ} \mathrm{C}$. As WSSV infection loads only increased briefly to peak at $24 \mathrm{hpi}$ in crayfish maintained at $32^{\circ} \mathrm{C}$, priming for elevated cellular apoptosis might be important in restricting WSSV replication and intracellular spread. This supposition is supported by findings in insect cells infected by Autographa californica nuclear polyhedrosis virus (AcMNPV), where apoptosis induced by virus mutants lacking a functional p35 gene dramatically 
decreased yields of progeny virus (Clem \& Miller 1993). Based on this observation, it was suggested that cell suicide was the likely mechanism preventing virus from multiplying and thus infecting naïve cells. The premature demise of a virus-infected cell, curtailing the ability of a virus to multiply and spread, is generally accepted as a pivotal antiviral defense mechanism (Flint et al. 2000).

In vertebrates, physiological stress caused by exposure to elevated temperatures alone is sufficient to induce cellular apoptosis (Ashish et al. 2009, Wang et al. 2009) or to suppress viral replication (Conti et al. 1999). Data reported here in Procaumbarus clarkii crayfish are consistent with these observations and shed additional light on the possible reasons why WSSV replication does not progress to cause acute disease and mortality at $32^{\circ} \mathrm{C}$ (Du et al. 2006). However, while elevated cellular apoptosis correlates well with virus suppression to low levels easily tolerated by the crayfish, as WSSV-infected crayfish maintained at $24^{\circ} \mathrm{C}$ also displayed evidence of apoptosis, priming, apoptosis levels or other as yet to be discovered virus-specific processes also seem likely to be involved.

Acknowledgements. This work was supported by National Natural Science Foundation of China (Grant No. 30901116) and Natural Science Foundation of Zhejiang Province of China (Grant No. Y3080212). We are indebted to Dr. Z. Li for valuable comments and suggestions.

\section{LITERATURE CITED}

Ashish N, Rachel SG, Nirav GS, Ishwar SS, Jeffrey DH (2009) Febrile-range hyperthermia accelerates caspasedependent apoptosis in human neutrophils. J Immunol 181:2636-2643

Barber GN (2001) Host defense, viruses and apoptosis. Cell Death Differ 8:113-126

Clem RJ, Miller LK (1993) Apoptosis reduces both the in vitro replication and the in vivo infectivity of baculovirus. J Virol 67:3730-3738

> Conti C, Marco AD, Mastromarino P, Tomao P, Santoro MG (1999) Antiviral effect of hyperthermic treatment in rhinovirus infection. Antimicrob Agents Chemother 43: 822-829

Du HH, Li WF, Xu ZR, Kil ZS (2006) Effect of hyperthermia on the replication of white spot syndrome virus (WSSV) in Procambarus clarkii. Dis Aquat Org 71:175-178

Du HH, Fu LL, Xu YX, Kil ZS, Xu ZR (2007) Improvement in a simple method for isolating white spot syndrome virus (WSSV) from the crayfish Procambarus clarkii. Aquaculture 262:532-534

> Durand SV, Lightner DV (2002) Quantitative real time PCR for the measurement of white spot syndrome virus in shrimp. J Fish Dis 25:381-389

Fang H, Beau JF, Andrew KG, Jimmy K (2006) White spot syndrome virus open reading frame 222 encodes a viral e3 ligase and mediates degradation of a host tumor suppressor via ubiquitination. Virology 80:3884-3892

Flint SJ, Enquist LW, Krug RM, Racaniello VR, Skalaka AM (2000) Principles of virology: molecular biology, pathogenesis and control. American Society for Microbiology, Washington, DC, p 518-551

Gao H, Kong J, Li ZJ, Xiao GX, Meng XH (2011) Quantitative analysis of temperature, salinity and $\mathrm{pH}$ on WSSV proliferation in Chinese shrimp Fenneropenaeus chinensis by real-time PCR. Aquaculture 312:26-31

Gerald MC (1997) Caspases: the executioners of apoptosis. Biochemistry 326:1-16

Granja CB, Aranguren LF, Vidal OM, Aragón L, Salazar M (2003) Does hyperthermia increase apoptosis in white spot syndrome virus (WSSV)-infected Litopenaeus vannamei? Dis Aquat Org 54:73-78

> Granja CB, Vidal OM, Parra G, Salazar M (2006) Hyperthermia reduces viral load of white spot syndrome virus in Penaeus vannamei. Dis Aquat Org 68:175-180

> Jiravanichpaisal P, Soderhall K, Soderhall I (2004) Effect of water temperature on the immune response and infectivity pattern of white spot syndrome virus (WSSV) in freshwater crayfish. Fish Shellfish Immunol 17: $265-275$

Khanobdee K, Soowannayan C, Flegel TW, Ubol S, Withyachumarnkul B (2002) Evidence for apoptosis correlated with mortality in the giant black tiger shrimp Penaeus monodon infected with yellow head virus. Dis Aquat Org 48:79-90

Koyama AH, Fukumori T, Fujita M, Irie H, Adachi A (2000) Physiological significance of apoptosis in animal virus infection. Microbes Infect 2:1111-1117

Lightner DV (1996) A handbook of pathology and diagnostic procedures for diseases of culture penaeid shrimp. World Aquaculture Society, Baton Rouge, LA

> O'Brien V (1998) Viruses and apoptosis. J Gen Virol 79: 1833-1845

Rahman MM, Escobedo-Bonilla CM, Corteel M, DantasLima JJ and others (2006) Effect of high water temperature $\left(33^{\circ} \mathrm{C}\right)$ on the clinical and virological outcome of experimental infections with white spot syndrome virus (WSSV) in specific pathogen free (SPF) Litopenaeus vannamei. Aquaculture 261:842-849

Sahtout AH, Hassan MD, Shariff M (2001) DNA fragmentation, an indicator of apoptosis in cultured black tiger shrimp Penaeus monodon infected with white spot syndrome virus. Dis Aquat Org 44:155-159

Sahul Hameed AS, Sarathi M, Sudhakaran R, Balasubramanian G, Syed Musthaq S (2006) Quantitative assessment of apoptotic hemocytes in white spot syndrome virus (WSSV)-infected penaeid shrimp, Penaeus monodon and Penaeus indicus, by flow cytometric analysis. Aquaculture 256:111-120

Söderhäll K, Cerenius L (1998) Role of the prophenoloxidase activating system in invertebrate immunity. Curr Opin Immunol 10:23-28

Vidal OM, Granja CB, Aranguren F, Brock JA, Salazar M (2001) A profound effect of hyperthermia on survival of Litopenaeus vannamei juveniles infected with white spot syndrome virus. J World Aquacult Soc 32:364-372

Vlak JM (2004) Nimaviridae. In: Fauquet CM, Mayo MA, Maniloff J, Desselberger U, Ball LA (eds) VIIIth report of the International Committee on Taxonomy of Viruses. Elsevier, Amsterdam, p 187-192

Wang YC, Lo CF, Chang PS, Kou GH (1998) Experimental 
infection of white spot baculovirus in some cultured and wild decapods in Taiwan. Aquaculture 164:221-231

Wang YT, Liu W, Seah JN, Lam CS, Xiang JH, Korzh V, Kwang J (2002) White spot syndrome virus (WSSV) infects specific hemocytes of the shrimp Penaeus merguiensis. Dis Aquat Org 52:249-259

Wang XQ, Gao XH, Li XD, Hong YX and others (2009) Local hyperthermia induces apoptosis of keratinocytes in both normal skin and condyloma acuminata via different pathways. Apoptosis 14:721-728

Wang ZM, Hu LB, Yi GH, Xu H, Qi YP, Yao LN (2004) ORF390 of white spot syndrome virus genome is iden-

Editorial responsibility: Jeff Cowley, Brisbane, Queensland, Australia tified as a novel anti-apoptosis gene. Biochem Biophys Res Commun 325:899-907

Withyachumnarnkul B, Boonsaeng V, Chomsoong R, Flegel TW, Muangsin S, Nash GL (2003) Seasonal variation in white spot syndrome virus-positive samples in broodstock and post-larvae of Penaeus monodon in Thailand. Dis Aquat Org 53:167-171

You X, Su Y, Mao Y, Liu M, Wang J, Zhang M, Wu C (2010) Effect of high water temperature on mortality, immune response and viral replication of WSSV-infected Marsupenaeus japonicas juveniles and adults. Aquaculture 305:133-137

Submitted: March 29, 2012; Accepted: September 4, 2012

Proofs received from author(s): November 8, 2012 